\title{
Angioma Serpiginosum
}

National Cancer Institute

\section{Source}

National Cancer Institute. Angioma Serpiginosum. NCI Thesaurus. Code C3926.

A hemangioma arising from the skin, presenting as a red dot. 